\title{
Comment
}

\section{THE ESTATE AND GIFT TAX AMENDMENTS: REVENUE ACT OF 1942}

\section{COMMUNITY PROPERTY}

Prior to the amendments contamed in the 1942 Act, the federal revenue laws were drawn without reference to the community property system. ${ }^{1}$ Congress left to the courts the task of determining the incidence of the federal income, estate and gift taxes on this unique type of tenancy. So complete is the control of the husband over cominunity property during coverture, ${ }^{2}$ that it has often been said that ". . . community is a partnership which begins only at its end." Nevertheless, the courts chose to ignore this question of control and seized instead upon the common-law concepts of "vested interest" and "expectancy" (which seem quite inappropriate for dealing with a peculiarly civil law institution) in order to determine the nature of the wife's property. Where they found that state law gave the wife a vested interest in the community property, as has been the case in all community property states since $1927,{ }^{4}$ they reached results advantageous to spouses resident in those states in comparison with couples otherwise identically situated but resident in non-community property states. Most notable was the holding that community income might be divided between the spouses for income tax purposes."

1 I PaUL, Federal Estate and Gifi Taxation (1942) § 1.09.

2 Altman argues convincingly that it is only at death that any substantial distinctions appear between the rights of the wife under the community property system and her rights elsewhere. Altman, Community Property: Avoiding Avoidance by Adoption in the Revenue Act (1938) 16 Tax Mag. 138, 140.

3 Arnett v. Reade (1911) 220 U. S. 311, 319. In the course of the opinion, Justice Holmes states that the quoted statement cannot be reconciled with the law of New Mexico. He finds it unnecessary to define precisely the wife's interest in commumity property in that state, contenting himself inerely by saying ". . . it is very plain that the wife has a greater interest than the inere possibility of an expectant heir." Ibid. at 320.

The wife's interest in community property defies classification in accordance with coinunon-law criteria. It is clearly sui generis. Daggett, The Modern Problem of the Nature of the Wife's Interest in Community Property-A Comparative Study (1931) 19 CaIIF. L. REv. 567, 572.

4 Prior to the adoption of Califorma Civil Code section 161a in 1927, the wife was held to have a mere expectancy in the cominunity estate in California. Consequently, the entire income from cominunity property was taxable to the husband. United States v. Robbins (1926) 269 U.S. 315. That the addition of section 161a gave the wife a vested interest in half of the community property and hence entitled her to return one-half of the community income for tax purposes was held in United States v. Malcolm (1931) 282 U. S. 792.

The Malcoln case narked the creation of a set of community property rules by the federal courts which have no counterpart in the state decisions. For full discussion of this point see Mitchell, Federal Taxation in Recent Contact with California Community Property (1941) 14 So. CaLIP. L. REv. 390.

5 Poe v. Seaborn (1930) 282 U. S. 101; Goodell v. Koch (1930) 282 U. S. 118; Hopkins v. Bacon (1930) 282 U. S. 122; Bender v. Pfaff (1930) 282 U. S. 127; United States v. Malcolm, supra note 4. 
Following the results reached in the income tax cases, the Treasury acquiesced in similar advantages with respect to the estate and gift taxes. ${ }^{6}$ For example, if the husband (having himself acquired the full amount of the community property) died first, only one-half of the community property was includible in his estate-a tax advantage only partially offset by the fact that if the wife died first one-half of the community property was held taxable to her estate. Similarly, gifts of community property were taxed as though each party had made a gift equal to one-half the total value thereof. ${ }^{7}$

Until this year efforts to deal with these inequalities were unavailing. In the 1942 Act, however, Congress dealt with the estate and gift taxes but left the income tax situation for another time. In the estate tax amendment Congress added a new subsection to section $811(\mathrm{e})^{8}$ (dealing with joint interests) under which all community property is included in the estate of the decedent spouse except so inuch as is shown to have been received or derived from compensation for services rendered by the surviving spouse. The last sentence in the subsection provides that in no case shall such interest be less than so much of the community estate as was subject to the decedent's power of testamentary disposition. This last sentence is iniportant and is designed to put at least half of the property into decedent's estate in any state of affairs. A new subsection is also added to section $811(\mathrm{~d})^{9}$ (dealing with revocable transfers) under

61 Paul, op. cit. supra note $1, \S 4.11$.

7 For further elaboration upon the divergencies incident to federal estate and gift taxation as it applied in community and non-community property states prior to the 1942 amendments see, Ray, Proposed Changes in Federal Taxation of Contmunity Property: Estate and Gift Taxes (1942) 30 CaLIF. L. REv. 527. 1 PaUL, op. cit. supra note $1, \S 4.11$.

8 Section 402 of the 1942 Act [Pob. L. No. 753, 77th Cong. 2d Sess. (Oct. 21, 1942)] added new paragrapi (2) to Internal Revenue Code section 811(e) [53 STAT. (1939) 121,26 U.S.C. (1940) § 811 (c)]:

"'(2) Confarunity INTERests.-To the extent of the mterest therem held as community property by the decedent and surviving spouse under the law of any State, Territory, or possession of the United States, or any foreign country, except such part thereof as may be shown to have been received as compensation for personal services actually rendered by the surviving spouse or derived originally from such compensation or from separate property of the surviving spouse. In no case shall such interest included in the gross estate of the decedent be less than the value of such part of the commumity property as was subject to the decedent's power of testamentary disposition."

${ }^{9}$ Section 402 of the 1942 Act added new paragraph (5) to Internal Revenue Code, section 811(d) [53 STAT. (1939) 121, 26 U. S. C. (1940) §811(d)]:

"'(5) Transfers of Commonutiy Property in Contearplation of Death, etc.For the purposes of this subsection and subsection (c), a transfer of property held as commumity property by the decedent and surviving spouse under the law of any State, Territory, or possession of the United States, or any foreign country, shall be considered to have been made by the decedent, except such part thereof as nuay be shown to have been received as compensation for personal services actually rendered by the surviving spouse or derived originally from such compensation or from separate property of the surviving spouse." " 
which if testamentary transfers are made inter vivos which would result in inclusion of the transferred property in the gross estate under sections 811(c) and 811(d) (these deal with transfers in contemplation of death, to take effect in possession or enjoyment at or after death, reserving life estates and power to revoke, alter or amend, and so forth) then such transfers shall be considered to have been made by the decedent except, again, where the property was received or derived from compensation for services rendered by the surviving spouse. The last sentence of the amendment to section 811 (e), relating to property over which decedent has power of testamentary disposition, does not appear in section 811 (d) because it deals with inter vivos transfers and at the death of the transferor there will not be any property over which the decedent transferor holds power of testamentary disposition.

In the gift tax amendment Congress provided that all gifts of community property "shall be considered to be" gifts of the husband except that gifts of property received or derived from compensation for personal services rendered by the wife "shall be considered to be" gifts of the wife. ${ }^{10}$

In adopting these amendments Congress made its choice among a variety of methods that might have been adopted to put taxpayers in the community property states on the same tax basis as taxpayers in other states. ${ }^{11}$ That, after all, was the foremost objective. ${ }^{12}$

Some Questions of Construction and Constitutionality.-The most obvious strategy open to the community property taxpayer will be an attack on the constitutionality of these amendments. This argument will focus on the propositions that the community property systems are not tax avoidance schemes, that they are local property rules under which property is held and transferred inter vivos and at death, that under these rules each spouse, during coverture, holds a vested interest in his share of the community property; and that any scheme of taxation that disregards these rules of legal ownership is violative of due process as an attempt to tax the property of $A$ as the property of $B .^{13}$

10 Internal Revenue Code $\S 1000$ (d), added by $\S 453$ of the 1942 Act provides:

"'(d) COMMUNTTY ProperTy.-All gifts of property held as community property under the law of any State, Territory, or possession of the United States, or any foreign country shall be considered to be the gifts of the husband except that gifts of such property as may be shown to have been received as compensation for personal services actually rendered by the wife or derived originally from such compensation or from separate property of the wife shall be considered to be gifts of the wife.'"

11 These are discussed in Ray, op. cit. supra note 7, at 533 .

12 See H. R. Rep. No. 2333 on H. R. 7378, 77th Cong. 2d Sess. (July 14, 1942) 35, 160; SeN. Rep. No. 1631 on H. R. 7378, 77th Cong. 2d Sess. (Oct. 2, 1942) 231.

13 Hoeper v. Tax Commission (1931) 284 U. S. 206. 
There is little force left in arguments of this sort today. The amendments operate in different ways in different fact situations so for the purpose of considering whatever force there may be in these arguments a brief outline of the operation of the new amendment follows. In all cases the status of the property as separate or community must first be determined under local law and in this connection it is important to note that community property may be acquired by the earnings of either husband or wife or both and it also may be acquired in other ways such as by gift to, or inheritance by, the community. The problem of tracing is still with us. In stating that the status of the property must first be determined under local law it is important to note that the new amendment has its own rule for determining the kind of community property that is to be excluded from the estate of the decedent. That rule is "... such part thereof as may be shown to have been received as compensation for personal services actually rendered by the surviving spouse or derived originally from such compensation or from separate property of the surviving spouse."14 This rule is designed to be a uniform federal rule. ${ }^{15}$ It is to be used to determine the property to be excluded regardless of its conformity to any local rule.

The following is an outline of the operation of the new amendment:

1. $H$ is sole earner and some property acquired otherwise:

(a) $H$ dies first-all included in his estate.

(b) $W$ dies first-one-half of all included in her estate where she has power of testamentary disposition. ${ }^{16}$

2. $W$ is sole earner and some community property acquired otherwise:

(a) W dies first-all included in her estate.

(b) $B$ dies first-one-half of all included in her estate where he has power of testamentary disposition.

14 Section 402 of amendment, see note 8 , supra.

16 This legislative purpose is stated in both the House and Senate Committee Reports accompanying the Bill as follows: 'Property 'derived originally from' compensation or from separate property of the surviving spouse includes (1) property acquired in exchange for property received as compensation or in exchange for separate property, (2) community mcome yielded by such property and property acquired with such income, and (3) property which may be traced back to property received as compensation, separate property, income from property received as compensation, or income from separate property. The statute establishes a uniform Federal rule for apportioning the respective contributions of the spouses regardless of varying local rules of apportionment. State presumptions are therefore not operative against the Commissioner." SEN. REP. No. 1631, op. cit. supra note 12, at 231-232; H. R. No. 2333, op. cit. supra note 12, at 160.

16 For the extent and nature of the spouse's power of testamentary disposition in 
3. $H$ and $W$ have each earned some proportion and some community property acquired otherwise:

(a) $H$ dies first-all included in his estate except part attributable to compensation for W's services but in no event shall amount included be less than one-half of all where he has power of testamentary disposition.

(b) $W$ dies first-all included in her estate except part attributable to compensation for $H^{\prime} s$ services but in no event shall amount included be less than one-half of all where he has power of testamentary disposition.

In case 1 (a) taxability focuses on the economic powers enjoyed by the husband over all the property. The new amendment cuts across the vested interests of the spouses and taxes to the husband's estate the full value of the community property. It will be argued that one-half of this property was already vested in the wife by local law, no part of it was in the husband's estate and hence it did not pass to her at his death.

Answer to this argument may be found in Tyler $v$. United States ${ }^{17}$ and United States $v$. Jacobs. ${ }^{18}$ While these cases dealt with tenancy by the entirety and joint tenancy, respectively, estates that differ in nature from the tenancy in community, the reasoning makes it clear that Congress need not confine itself to.transfers of title in a technical sense, nor need it look solely to the consequences of death upon the decedent's legal estate in enacting a valid death duty. The $A$ and $B$ argument is not likely to prevail today.

the community property states, see CAI. ProB. Code $\$ 201$ (formerly Civil Code $\$ \S 1401-$ 1402); ARIZ. CODE (1939) § 39-109; IDAHO CODE (1932) \& 14-113; LA. Crv. CodE (Dart, 1932) $\$ \S 915,916$ (where the power of each is clearly implied); Okla. Stats. 1941, tit. 32, \$ 65; Sutton v. Harvey (1900) 24 Tex. Civ. App. 26, 57 S. W. 879; WaSH. Rev. Stat. (Remington, 1932) \& 1342.

In New Mexico and Nevada the wife has no power of testamentary disposition over her share of the community estate. NEv. Comp. LAws (Supp. 1942) §3395.01; N. M. StaT. (Courtright, 1929) $\$ 38-104$. It would seem then that under the wording of the new amendment, in these two states where the wife is the decedent, her husband having earned all the conmunity property, there would be no estate tax levied upon the commumity property.

In California before 1923, the wife had no power of testamentary disposition, and it has been held by the California Supreme Court in McKay v. Lauriston (1928) 204 Cal. 557, 269 Pac. 519, that it would be an unconstitutional interference with the husband's vested rights to apply this power to conımunity property acquired before 1923 . It would seem then that as to commumity estate acquired before this date the situation will be the same as that in New Mexico. .

17 (1930) 281 U.S. 497.

18 (1939) 306 U. S. 363. 
The following language from the Tyler case, which was relied on in the Jacobs case, is pertinent:

"The question here, then, is, not whether there has been, in the strict sense of the word, a 'transfer' of the property by the death of the decedent, or a receipt of it by right of succession, but whether the death has brought into being or ripened for the survivor, property rights of such character as to make appropriate the inposition of a tax upon that result ... to be measured, in whole or in part, by the value of such rights." 19

\section{The Court states further,}

"At his death, however, and because of it, she, for the first time, became entitled to the exclusive possession, use and enjoyment; she ceased to hold the property subject to qualifications imposed by the law relating to tenancy by the entirety, [here the words 'community property' may be convemently substituted] and became entitled to hold and enjoy it absolutely as her own. ... Thus the death of one of the parties became the 'generating source' of important and definite accessions to the property rights of the other." 20

Since the wife now has her vested interest free from all restrictions as to its use, that is, from the restrictions of the husband's powers of management and control, ${ }^{21}$ it is obvious that the above quoted language is appropriate to sustain the tax in the community property situation.

Although estate taxation of joint tenancies and tenancies by the entirety is based upon the fact that these forms of property ownership are attended by the right of survivorship, there is in effect a right of survivorship in the community property system-to the extent of the vested interest of the survivor, ${ }^{22}$ which passes to him absolutely upon the decedent's death.

In our case $1(b)$ where the wife dies first, taxability focuses on the legal title of the wife to one-half and disregards her lack of powers of managenient during her lifetime. ${ }^{23}$ In addition the power of

19 Supra note 17, at 503.

$20 \mathrm{Ibid}$. at 504.

21 See 3 VERNIER, AXIERICAN FAMIII LATwS (1935) § 178, setting out the few limitations upon the husband's complete powers of management and control. It is sufficient to say that, with minor exceptions, the wife is without statutory power to manage or dispose of commumity property.

22 In Nevada and New Mexico there is such a right to the full value of the community estate where the wife is the decedent. See note 16, supra.

23 In California, as to community property acquired before 1927, the wife bad only an expectancy. Stewart v. Stewart (1928) $204 \mathrm{Cal}$. 546, 269 Pac. 439. Although as to community property acquired subsequent to 1923 she had testamentary disposition of one-half (see note 4, supra), her interest was not regarded as vested, at least for federal 
testamentary disposition is well recognized as a proper basis for an excise tax measured by the extent of that power. ${ }^{24}$

In case 2(a) where the wife has been the sole earner and dies first, the argument for the constitutionality of taxing her estate upon any part of the husband's vested one-half interest becomes a little more tenuous. In three states the wife has management and control over community property derived from her earmings ${ }^{25}$ so in these states the argument, as to this much of the property, presents no difficulty. But as to the rest of the property and as to all of it in the other commumity property states she has no such power. The husband holds not only legal title to one-half but also has full powers of management. It may be asked what increase in rights as to his vested one-half interest does the husband receive upon the death of his wife. In other words, is the release of the husband from the few limitations on his powers of management and control sufficient to sustain the validity of an excise tax measured by the value of his vested one-half of the community?

In California, before his wife's death, the husband may not give away his (or her) half interest in any community property nor may he sell his (or her) half interest in community realty. ${ }^{20}$ Her death gives him these added powers. The question then is simply whether the Supreme Court will find enough in this increase in the survivor's powers over his property to support an estate tax. It will also be argued that at least as to so much of the property as is traceable to the wife's earnings, taxability may properly rest on the important fact that she contributed to the acquisition of it and this basis is recognized in the taxation of property held in joint tenancy or by the entirety. ${ }^{27}$

income tax purposes, until 1927. United States v. Malcoln, supra note 4. As to property acquired before 1923 over which the wife has no testamentary power, and no vested interest therein, it is hard to find a basis for taxability in case 1 (b). It should be noted that as to commumity property acquired before 1917 the increase of the husband's rights upon his wife's death is even less in California because prior to that date (when California Civil Code section 172a was adopted) the husband could dispose of community realty without his wife's consent. In Roberts v. Wehmeyer (1923) 191 Cal. 601, 218 Pac. 22, it was held that section 172a could not be applied retroactively.

However, in California since 1891 (CAL.Crv. CODE \$172) the husband has no power to give away community property. The situation is the same in the other community property states. Altman, op. cit. supra note 2 , at 139 . Thus it appears that the husband, upon the wife's death receives at least the unhampered right to give away any portion of the community property-a power which he could exercise during coverture only with his wife's consent.

24 New York Trust Co. v. Eisner (1921) 256 U. S. 345.

25 IDAHo CODE (1932) §31:913; NEv. CoMp. Laws (Hillyer, 1929) §3360; Okla. Stats. 1941, tit. $32, \S 56$.

26 CAL. CIv. CODE $\S \S 172,172 a$.

27 I. R. C. $\$ 811$ (e) [53 STAT. (1939) 122, 26 U.S. C. (1940) $\S 811(e)]$. 
Case 2(b) is the same as case 1 (b) with the added power of manageinent in the husband. Cases $3(\mathrm{a})$ and (b) are sinply combinations of the cases just considered.

It is curious to see how the argument shifts from economic controls of varying degrees to bare legal title to a coinbination of both and to regard for the spouse to whoin the property is attributable. The fact of the matter is that the drafters have in this way achieved a maximum of taxability.

As to the new gift tax amendment, it would seem that taxation to the husband of the value of the gifts of community property, although the value of the wife's vested interest is included therein, will stand or fall upon substantially the same constitutional arguments as those applied to the estate tax provisions. Is the act of the husband in divesting himself of his legal title to one-half and his powers of management and control over the whole sufficient to support a gift tax measured by the total value of the property given?

If the gift is of property derived from earnings of the wife, however, the gift tax under this amendment is imposed on the wife. In three states the wife has power of inanagenent and control over this property $^{28}$ and in these states the issue will be the same as stated above. In the other community property states, however, the husband has management and control over this property yet the tax is inposed on the wife. The excise, as to the husband's half interest, might be supported as levied on her exercise of her power to consent to the making of gifts from the community estate. This may turn out to be too insignificant to support the tax for in all cases there must be the consent of both spouses before a gift may be made. The consent of either spouse, standing alone, has hitle significance.

Some Questions under the Gift Tax Amendment.-The gift tax has been treated, throughout its history, as a sort of appendage to the estate tax. ${ }^{29}$ In keeping with this idea the gift tax annendment ${ }^{30}$ is designed to correlate the gift tax with the amendments to the estate tax.

The advantages enjoyed by taxpayers in community property states with respect to the estate and incoine tax are equally applicable to the gift tax. The legislative atternpt to neutralize this advantage has taken substantially the same approach with the gift tax as it has with the estate tax-except for the inexplicable fact that the estate tax amendinents became effective upon passage of the act whereas the gift tax amendinents are not effective until January $1,19433^{31}$

\footnotetext{
28 Idaho, Nevada and Oklahoma. See note 24, supra.

292 PAUL, op. cit. supra note 1 , at \$15.04.

30 See note 10, supra.

31 Revenue Act of 1942, $\$ \S 401,451$.
} 
The amendment to the gift tax provides, as we have seen, that a gift of property held as community property "shall be considered to be" the gift of the husband, except that gifts of property shown to have been received as compensation for personal services of the wife "shall be considered to be" gifts of the wife. ${ }^{32}$ This scheme of taxation follows the pattern of the estate tax amendment in denying recognition to the interests created by the community property law in a non-earning wife.

In the simple situation where a gift is made to a person outside the commumity there is no difficulty. The amendment plainly taxes the gift as a gift of the husband unless the property was derived from the wife's earnings in which case it is taxed as her gift. Less amenable to ready analysis is the situation where community property is given to one of the.spouses. Some startling tax consequences follow under the language of the amendment. Thus, where the husband makes a gift to his non-earning wife he is taxable on the full value of the property. This result carries out the purpose of the amendment and is the sanie as in a non-community property state where the earming husband nakes a gift to his wife. But where a non-earming wife makes a gift to him, then he nust still pay a tax on the full value. This is surely an anonialous result and plainly it not only removes the advantage heretofore enjoyed by taxpayers in community property states but puts then at a distinct disadvantage. The same odd result follows when a husband makes a gift to his wife of community property derived from her earnings if that property is community property under local law.

Results such as these call for further analysis to see if there is not sonie way by which they may be avoided. The transfers have effected an alteration in the manner in which the property is held and this is doubtless an appropriate occasion for the imposition of an excise tax. Is there, however, a gift? The argument in favor of recognizing the vested mterest of each spouse and thus rejecting the existence of a gift is strongest when the community is severed by divorce. Unless otherwise provided in a property settlement or divorce decree the spouses thereafter hold the property as tenants in common. ${ }^{33}$ Apparently there has never been any attempt to impose a gift tax in this situation. ${ }^{34}$ It is arguable that the same result should follow from an agreement of the spouses to.hold their property in some other form of tenancy or to divide it equally, but the most potent warning against this construction is that it would virtually nullify the

32 See note 10, supra.

332 VERNIER, op. cit. supra note 21, at 253.

34 Hines, Tax Aspects of Property Settlement Agreements (1939) 12 So. CALIF. L. REv. 386, 388 et seq. 
amendment. Another possible construction would be that this amendment pays attention to the spouse to whom the property is economically attributable. This is explicit in the case of the wife and may be carried over to the case of the husband, and thus a taxable gift occurs only when it is made to any person other than the spouse to whom it is economically attributable. This is a tenable view and it has the distinct merit of avoiding the hardships mentioned above and at the same time accomplishing the objectives of the amendment to the full.

Another problem is presented where the donor spouse retains some string on the property so that the gift is incomplete. ${ }^{35}$ It would seem that the question as to whether there has been a taxable "gift" of community property should be decided first with reference to the completeness of the gift as far as the commumity, rather than the donor spouse alone, is concerned before the amendment is brought into play to determine the measure of the tax and then impose it on one or the other spouse. It would be a harsh result if the literal language of the amendment were applied to tax the spouse who was not the donor because as far as he is concerned no strimg was retained in his favor and the gift is complete. ${ }^{36}$

Deductions.-The deductibility of community debts is not dealt with by these amendments. But in the simple case where the entire community property is included in the estate of the decedent husband, who has been the sole contributor to the community, the question arises as to what portion of the community debts will be deductible from his estate,

Heretofore, it has been held in Washington that the decedenthusband is only entitled to a deduction of one-half of the community debts from his gross estate because each one-half of the community property is subject to commumity debts under local law. ${ }^{37}$ Although the California executor is allowed to deduct the full amount of decedent's personal debts, ${ }^{38}$ he may not deduct more than one-half of the community debts. ${ }^{39}$ This was fair enough when only one-half the

35 Such as a power to revoke under Burnet v. Guggenheim (1933) 288 U. S. 280, or a power to change beneficiaries under Estate of Sanford v. Commissioner (1939) 308 U.S. 39. Much the same problem is presented where the donor spouse retams a life interest in the income so that as to the donor the gift tax would apply only to the value of the remainder, 2 PAUL, op. cit. supra note $1, \$ 17.12$. See Herzog v. Commissioner (C.C.A.2d, 1941) 116 F. (2d) 591, where this gift tax consequence was assumed.

36 An example of this situation would be when $H$ makes a gift of community property attributable to $W$ 's earnings and retains a string in his favor. $W$ in this case is the taxpayer and as to her the gift is complete.

37 Lang's Estate v. Commissioner (C. C. A. 9th, 1938) 97 F. (2d) 867.

38 United States v. Goodyear (C. C. A. 9th, 1938) 99 F. (2d) 523.

39 Estate of Crail (B.T.A. Memo. Op. June 30, 1942) C. C. H. Inher. Tax Serv.

(7th ed.) II 7194. 
community property was included in the gross estate but under the new amendments this may no longer be the case. His estate should be entitled to a deduction of the full amount of community debts. Where the non-earning spouse dies first, one-half of the community debts should be deductible since only one-half of the community property is included in the gross estate. It remains to be seen whether these results can be extracted from the general provision of Internal Revenue Code section 812 (b) (3) regarding deduction of "claims against the estate" or whether a further amendment will be required. Fairness surely calls for a reexamination of this question. The matter nnay be taken care of by a direction in decedent's will that all clainis may be satisfied out of decedent's taxable estate. ${ }^{40}$

Tax Consequences and Some Steps That May be Taken.-The avowed purpose of the new community property aniendments was to eliminate the inequalities in estate and gift taxation as between taxpayers in community and non-community property states. ${ }^{41}$ In a community property state the decedent is now treated as the owner of all comnunity property for estate tax purposes except as to that portion contributed by the efforts of the other spouse. This works out equitably when the husband predeceases the wife and has been the sole earner or in the converse situation. The tax paid in both cases will be the same as that paid in a non-commumity property state and the amendments thus achieve their purpose.

But when the wife predeceases the husband, he having contributed all the community property, or the husband predeceases the wife, she having earned all the community property, one-half will be included in the estate of the decedent if he (or she as the case may be) had power of testamentary disposition over that portion. ${ }^{42}$ In a similar situation in a non-community property state nothing is included in the decedent's estate since he (or she) would have no power of testamentary disposition over the survivor's earnings. In this situation, then, the community estate will ultimately be taxed one and one-half times if the estate is left to the survivor, unless the survivor should die within five years of the prior spouse and so be entitled to the deduction provided by section 812 (c) of the Internal Revenue Code. ${ }^{43}$ On a similar state of facts in a non-community property state

${ }^{40}$ See 1 PaUL, op. cit. supra note $1, \S 11.25$. See also the diverse rules as to funeral and administration expenses, ibid. $\$ \S 11.10,11.18$.

41 Supra note 12.

42 See note 8 , supra.

4353 STAT. (1939) 124, 26 U. S. C. ' (1940) $\$ 812$ (c). This section permits a deduction from the decedent's gross estate of an amount equal to the value of any property acquired from the estate of one who has died within five years of decedent, if an estate tax was paid, or if it was acquired by gift within the same period and a gift tax was paid. 
the estate will only be taxed once-n the death of the surviving earner. Thus an attempt by Congress to overcome the advantage formerly held by community property taxpayers has resulted in subjecting them to a disadvantage. ${ }^{44}$ In two community property states there will be no discrimination since the decedent wife in Nevada and New Mexico has no power of testamentary disposition over community property (with certain exceptions). Such property goes to the surviving husband without administration. ${ }^{45}$

In order to effect the purpose of the amendments which was to equalize taxation in commumity and non-community states, it is submitted that a further amendment to 812 (c) ${ }^{46}$ shonld be made so that the estate of the surviving earner is permitted a deduction for the value of the community property taxed in the estate of the prior decedent when that property has gone to the survivor. This deduction should be applicable irrespective of the length of time elapsing between the deaths of the two spouses.

The situation created by this amendment will surely prompt taxpayers to seek means to put the one-half interest held by the nonearning spouse out of his or her power of testamentary disposition so that on his or her predecease one-half will not be included in the gross estate. In this connection the most important point to note is that there is a striking difference between the amendments to $811(\mathrm{e})$ and (d)..$^{47}$ The former provides that the entire community property is included in the decedent's gross estate except property earned by the other spouse and "In no case shall such interest included in the gross estate of the decedent be less than the value of such part of the community property as was subject to the decedent's power of testamentary disposition." 48 But the latter amendment does not include this italicized phrase. It provides that inter vivos transfers of community property in contemplation of death, revocable transfers, transfers reserving life estates, and so forth, shall be considered to have been made by the decedent except where the property was earned by the other spouse. The italicized phrase has no place in 811 (d) for that amendment deals with inter vivos transfers and when they have been made there is no property left over which de-

44 See 1 PaUL, op. cit. supra note $1, \S 4.11, \mathrm{n}$. 75, where the contention is made that the same thing occurs when two joint tenants have contributed equally to the joint tenancy and that this is merely a tax on the more extensive rights which the survivor acquires. However, this argument overlooks the fact that the creation of a joint tenancy is voluntary while the community estate exists by virtue of legal mandate. If the spouses attempt to take the property out of the community, it can only be done at the price of a gift tax.

45 Note 16, supra.

16 Note 44, supra.

47 Notes 8 and 9 , supra.

28 Italics added. 
cedent could have any power of testamentary disposition. The result is that where the non-earning spouse dies, having made a transfer in contemplation of death, for example, no part of the property so transferred is included in his or her estate since the property comes within the exception to 811 (d). It was not earned by the transferor. It is not includible in decedent's estate under 811 (e), of course, since decedent no longer has power of testamentary disposition over the property. It has been given away. This saving of an estate tax can be had, however, only at the cost of a gift tax on the transfer payable under the gift tax amendment. There may be many variations of this same idea and the question whether the transfer may be made only at the cost of a gift tax will depend upon the construction given to the gift tax amendment with respect to transfers where the donor spouse retains some string. ${ }^{49}$

The gift tax point is important, too, if the spouses enter into an agreement to hold all community property as tenants in common. This effectively converts the community property into the separate property of each spouse.

\section{IIFE INSURANCE}

The' simple language of the provision in the estate tax for the inclusion of life insurance proceeds in the estate of a decedent ${ }^{50}$ has remained unchanged since it first made its appearance in the Revenue Act of $1918 .^{51}$ During this span of twenty-four years it has taken on such a variety of meanings at the hands of courts and Treasury ${ }^{62}$ that Mr. Randolph Paul, writing in 1942, said that ". . . only the most gifted oracles are capable of guiding the insured along paths of safety." ${ }^{53}$ It was high time for Congress to take a hand and try to anchor the meaning of this important provision somewhere. We are, as it happens, the most insured people in the world and insurance has for a long time been a popular-and quite proper-method of tax avoidance.

The latest position taken by the Treasury under the old provision

${ }^{40}$ See text to note 36 , supra.

c0 53 STaT. (1939) 122, 26 U.S. C. (1940) $\$ 811$ (g).

"The value of the gross estate of the decedent shall be determined by including the value at the time of his death of all property, real or personal, tangible or intangible, wherever situated, except real property situated outside of the United States-

"(g) To the extent of the amount receivable by the executor as insurance under pohicies taken out by the decedent upon his own hife; and to the extent of the excess over $\$ 40,000$ of the amount receivable by all other beneficiaries as insurance under policies taken out by the decedent upon his own hife."

51 Revenue Act of 1918, 40 STAT. (1919) 1098.

v2 1 PaUL, op. cit. supra note 1, c. 10.

63 Ibid. at 570 . 
was announced in T. D. 5032 of January 10, 1941. Under this, insurance proceeds payable to some beneficiary other than the estate were included in the estate if the insurance was taken out and premiums were paid by the decedent after that date. Payment of premiums was the criterion for taxability. If, however, the insurance had been taken out before that date then taxability followed only if decedent held so-called "incidents of ownership" ${ }^{55}$ over the policy after that date.

The 1942 amendment ${ }^{56}$ discards the old provision and writes a

54 1941-1 C. B. 427, now contained in U. S. Treas. Reg. 105 (1942) $\$ \$ 81.25,81.27$. See the excellent discussion of this whole subject in Schlesinger, Taxes and Insurance: A Suggested Solution to the Uncertain Cost of Dying (1941) 55 HARv. L. REv. 226.

50 This term is used in the new annendment and the Report of the House Ways and Means Committee has this to say about it: "Examples of such incidents are the right of the insured or his estate to the economic benefits of the insurance, the power to change the beneficiary, the power to surrender or cancel the policy, the power to assign it, the power to revoke an assignment, the power to pledge the policy for a loan, or the power to obtain from the insurer a loan against the surrender value of the policy. Incidents of ownership are not confined to those possessed by the decedent in a technical legal sense. For example, a power to change the beneficiary reserved to a corporation of which the decedent is the sole stockholder is an incident of ownership in the decedent." $H$. R. REP. No. 2333 , op. cit. supra note 12, at 163. U. S. Treas. Reg. 105 (1942) § 81.27, under the old provision contains a like enumeration.

$\checkmark 8$ For convelience the entire amendment is set forth below:

"SEC. 404. ProceEdS OF LIFE INSURANCE.

"(a) General Rule.-Section 811 (g) [53 STAT. (1939) 122, 26 U.S.C. (1940) $\S 811(\mathrm{~g})$ ] (relating to life insurance) is amended to read as follows:

"' (g) Proceeds of Life Insurance.-

“(1) RECETVABLE BY THE EXECUTOR.-To the extent of the amount receivable by the executor as insurance under policies upon the life of the decedent.

" '(2) RECEIVABLE BY OTHER BENEFICTARIES.-To the extent of the amount receivable by all other beneficiaries as insurance under policies upon the life of the decedent (A) purchased with premiums, or other consideration, paid directly or indirectly by the decedent, in proportion that the amount so paid by the decedent bears to the total premiums paid for the insurance, or $(B)$ with respect to which the decedent possessed at his death any of the incidents of ownership, exercisable either alone or in conjunction with any other person. For the purpose of clause (A) of this paragraph, if the decedent transferred, by assignment or otherwise, a policy of imsurance, the amount paid directly or imdirectly by the decedent shall be reduced by an amount which bears the same ratio to the amount paid directly or indirectly by the decedent as the consideration in money or money's worth received by the decedent for the transfer bears to the value of the policy at the time of the transfer. For the purposes of clause (B) of this paragraph, the term "incident of ownership" does not include a reversionary interest.

"'(3) TRANSFER NOT A GIFT.-The amount receivable under a policy of insurance transferred, by assignment or otherwise, by the decedent shall not be includible under paragraph (2) (A) if the transfer did not constitute a gift, in whole or in part, under Chapter 4 , or, in case the transfer was made at a time when Chapter 4 was not in effect, would not have constituted a gift, in whole or in part, under such chapter had it been in effect at such time.

"'(4) COMArUNITY PROPERTY.-For the purposes of this subsection, premiums or other consideration paid with property held as community property by the insured and surviving spouse under the law of any State, Territory, or 
new one that in substance puts T.D. 5032 into the Internal Revenue Code with some new features.

The classification of life insurance proceeds into those (1) receivable by the executor and (2) those receivable by all other beneficiaries is retained-although the special $\$ 40,000$ exemption of insurance payable to the latter class has been eliminated. ${ }^{67}$ Also eliminated is the phrase "policies taken out by the decedent" which was an important source of confusion in the past. ${ }^{58}$

As formerly, proceeds receivable by the executor are includible in the gross estate, and as to these proceeds it is immaterial whether the decedent or another person paid the premiums. ${ }^{.0}$ The proceeds receivable by all other beneficiaries are to be included in the gross estate if (A) the premiums or other consideration for the insurance were paid directly or indirectly by the decedent, or $(B)$ if at the time of his death decedent possessed any "incidents of ownership"

possession of the United States, or any foreign country, shall be considered to have been paid by the insured, except such part thereof as may be shown to have been received as compensation for personal services actually rendered by the surviving spouse or derived origimally from such compensation or from separate property of the surviving spouse; and the term "imcidents of ownership" includes incidents of ownership possessed by the decedent at his death as manager of the community.'

"(b) Liability of Life Insurance Beneficiaries.-Section 826(c) [53 Stax. (1939) 128,26 U.S.C. (1041) $\S 826 \mathrm{c}$ ] (relating to apportionment of liability of beneficiaries) is amended to read as follows:

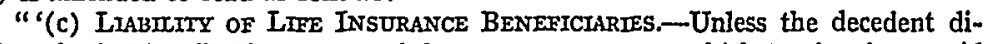
rects otherwise in his will, if any part of the gross estate upon which tax has been paid consists of proceeds of policies of insurance upon the life of the decedent receivable by a beneficiary other than the executor, the executor shall be entitled to recover from such beneficiary such portion of the total tax paid as the proceeds of sucli policies bear to the sum of the net estate and the amount of the exemption allowed in computing the net estate, determined under section 935 (c). If there is more than one such beneficiary the executor slall be entitled to recover from such beneficiaries in the same ratio.'

"(c) DECEDENTS To WHICH AMENDMENTS APPLICABLE.-The amendments made by subsection (a) shall be applicable only to estates of decedents dying after the date of the enactment of this Act; but in determining the proportion of the premiums or other consideration paid directly or indirectly by the decedent (but not the total premiums paid) the amount so paid by the decedent on or before January 10,1941, shall be excluded if at no time after such date the decedent possessed an incident of ownership in the policy."

57 In relation to this elimination should be considered section 414 of the Revenue Act of 1942 whicl amends I. R. C. section 935(c) [53 STAT. (1939) 141, 26 U.S.C. (1940) $\$ 935(c)]$ and provides that in the case of decedents dying after the enactment of the Act, the exemption for the additional estate tax will be $\$ 60,000$ instend of the present $\$ 40,000$. Thus is removed a discrimination between persons who are insured and those who are not as well as a reduction in the maximum amount of exemption formerly possible.

58 See 1 PaUT, op. cit. supra note $1, \$ 10.12$.

69 This was the view taken under the old provision and there is no reason to suppose that there will be any change under the new amendment, U. S. Treas. Reg. 105 (1942) \$81.26.

60 See note 55 , supra. 
cisable either alone or in conjunction with any other person. ${ }^{81}$ If either of these criteria is satisfied the proceeds are includible in the gross estate but this amendment contains the same provision as to retroactivity that is found in T.D. 5032 and it is fixed as of the same date, January 10, 1941. Thus, unless decedent held "incidents of ownership" under (B) after that date the premiums paid before that date are to be excluded. If the decedent paid only part of the consideration, the proceeds will be included in proportion that the amount so paid bears to the total premiums paid for the insurance. The amendment continues the same words to cover premiums paid "directly or indirectly" by the decedent. ${ }^{62}$ For the purpose of criterion (B) the amendment expressly provides that the term "incident of ownership" does not include a reversionary interest.

Apart from the community property provision, to be considered later, the foregoing are the important features of the new amendment. Even a quick look at the history of the old provision is enough to warn against the conclusion that all of the difficulties that have beset life insurance have been removed by any magic in this amendment. However, an important legislative step has been taken and some difficulties have been eliminated. The bother about whether a policy was "taken out by the decedent" under the old provision is now a thing of the past. The abolition of the special $\$ 40,000$ insurance exemption where the proceeds are payable to a beneficiary other than the estate carries with it the end of the questions as to whether combination annuity and insurance policies were entitled to the old special exemption ${ }^{63}$ but it leaves still with us the question as to whether the proceeds are taxable under the new amendment as "insurance" or under some other provision of the Code.

The importance of the amendment is that in its prospective operation after January 10,1941, it sets up two distinct criteria of taxability. One is payment of premiums and that alone is enough even though decedent has in his lifetime irrevocably parted with all his interest in the policy and the proceeds.

Here we have, by the payment of premiums, irrevocable inter vivos transfers of property not in contemplation of death, yet at death the amendment throws the proceeds of the policy into decedent's estate. This provision presents a new constitutional question but it will surely be sustained against attack on constitutional grounds.

61 The phrase "in conjunction with any other person" is obviously derived from I. R. C. section 811 (d) relating to revocable transfers sustained in Helvering v. City Bank Co. (1935) 296 U. S. 85.

62 Illustrative examples of indirect payment of premiums are given in H. R. REP. No. 2333 , op. cit. supra note 12 , at 162-163.

63 See Helvering v. Le Gierse (1941) 312 U.S. 531 ; Estate of Keller v. Commissioner (1941) 312 U.S. 543; Note (1940) 49 YaLE L. J. 946; (1942) 42 CoL. L. REV. 162. 
It is not even necessary to employ the argument that the provision is reasonably calculated to prevent avoidance of the estate tax ${ }^{84}$ for emphasis may be placed on the essentially testamentary quality of insurance and on the fact that the death of the decedent is the generating source of important rights in the beneficiary. ${ }^{65}$

The other and alternative criterion of taxability is the possession of "incidents of ownership" by the decedent at his death. In its prospective operation this is in no way tied up with the premium payment basis. It would thus command taxability in a case where, for example, a wife took out a policy on her husband's life, paid all the premiums out of her own property, named the children as beneficiaries and gave to her husband an "incident of ownership", such as power to change beneficiaries except in favor of himself. On his death the proceeds would be includible in his estate under the amendment. There will be a real battle over constitutionality in a case like this. It will be argued that decedent's only contribution to the vesting of the proceeds in the beneficiaries was that he died. His death brought about the vesting but that is all. On the other hand it may be argued that in other instances property may be included in decedent's estate even though he transferred it irrevocably during his lifetime and at his death held no power by which he could get it back. ${ }^{66}$ But it will be answered that in all of these cases the property originally belonged to the decedent and it was he who made the transfer. Perhaps the inost persuasive analogy to support the new insurance amendment is the power of appointment held by decedent over property which came from some other source. ${ }^{67}$

In the example given above it should be noted that if the wife did not give the husband any "incident of ownership" but retained them all herself and paid all the premiums the proceeds would not be includible in his estate and, since the proceeds would be payable on his prior death, they would obviously not be taxable in her estate. If, however, she died first and held "incidents of ownership" it is likely that at least the cash surrender value at the date of her death would be includible in her estate as an "interest" in property under I.R.C. section 811 (a). ${ }^{68}$

64 This argument was employed in Helvering v. City Bank Co., supra note 61, and Helvering v. Bullard (1938) 303 U. S. 297.

65 The constitutional arguments are more fully developed in 1 PAOL, op. cit. supra note $1, \S 10.15$.

66 Porter v. Commissioner (1933) 288 U. S. 436 ; Helvering v. Hallock (1940) 309 U.S. 106, and other cases may be cited for this.

${ }^{67}$ See the discussion-infra, and Morgan v. Commissioner (1940) 309 U. S. 78; Helvering v. Safe Deposit Co. (April 13, 1942) 316 U. S. 56.

68 U. S. Treas. Reg. 105 (1942) $\$ 81.25$, now suggests that if insurance proceeds are not includible under section $811(\mathrm{~g})$ they may be includible under some other section. On this point see Schlesinger, op. cit. supra note 54. Doubtless this idea will be carried 
It must be plain by now that while the new amendment was badly needed and does much to clarify the present confusion it still leaves many puzzles.

The problem of correlation of gift and estate taxes is still with us but the amendment also clarifies this situation. Under Helvering $v$. Hallock $^{69}$ it is now plain enough that the retention by a transferor of property of a reversionary imterest is enough of a string to subject the transferred property-or some part of it - to an estate tax on his death. This case has recently been applied to the retention of a similar string on insurance proceeds. ${ }^{70}$ The new amendment contains a legislative reversal of this extension of the Hallock case. It provides that ". . . the term 'incident of ownership' does not include a reversionary interest." ${ }^{71}$ What about the gift tax now? Under the gift tax, as now applied, the retention of a reversionary interest is not a sufficient string to make the gift incomplete. ${ }^{22}$ The gift tax applies, then. Under the new insurance amendment the estate tax does not apply when taxability depends upon the "incident of ownership" criterion under $2(B)^{73}$ for the amendment tells us that a reversionary interest is not such an incident. Thus far correlation is achieved. But when the policy is taken out after that date and no string is retained then each premium payment is a taxable gift ${ }^{74}$ and the proceeds are also taxable in decedent's estate under the premium payment basis of 2(A). Correlation is not achieved here. The insured is left to do his own correlating and he may do it if he retains a string, other than a reversionary interest, sufficient to make the gift incomplete for gift tax purposes. ${ }^{75}$

A specific provision in the new amendment deals with community property interests in the field of insurance. Previously the Treasury had relied on the "incidents of ownership" test in order to include in the gross estate the entire proceeds of a policy, not payable to decedent's estate and purchased with community funds. ${ }^{70}$ In Lang $v$.

into the Regulations to be issued under the amendment. Section 811 (f) may be used where decedent holds a power to change beneficiaries or perhaps section $811(c)$ in that possession or enjoyinent shifts at death.

${ }^{69}$ Supra note 66.

70 Chase Nat. Bank v. United States (C. C. A. 2d, 1940) 116 F. (2d) 625 ; Bailey v. United States (Ct. Cl. 1940) 31 Fed. Supp. 778.

$71 \S 404(\mathrm{a})(\mathrm{g})-2$ of the amendment.

72 U. S. Treas. Reg. 79 (1936) art. 2(5).

73 See note 49 , supra.

74 U. S. Treas. Reg. 79 (1936) art. 2(6). These payments would, of course, be entitled to the annual exclusion of $\$ 3000$ after January 1, 1943; see I. R. C. $\$ 1003$ (b) (2) as ainended by Revenue Act of $1942, \$ 454$.

75 See U. S. Treas. Reg. 79 (1936) art. 3, for instances of this and such cases as Burnet v. Guggenheim, and Estate of Sanford v. Commissioner, both supra note 35.

76 Newman v. Commissioner (C. C.A. 5th, 1935) 76 F. (2d) 449; Bank of America National Trust \& Savings Ass'n v. Commissioner (C. C. A. 9th, 1937) 90 F. (2d) 981. 
Commissioner ${ }^{77}$ the Supreme Court refused to allow the mclusion of more than half of the proceeds in the gross estate where the premiums had been paid with community property. In this case the "incidents of ownership" test was rejected, and the decision rested upon the ownership by the wife of one-half of the community funds used in paying premiums. The Lang case has been followed under the law of several other community property states, ${ }^{78}$ and was the last word on the subject until the present act.

The new amendment cuts across the legal interests held by the spouses under local law and provides that premiums paid with community property "shall be considered to have been paid by the insured" except such part as may be shown to have been paid out of compensation for services rendered by the surviving spouse or to have been derived from such compensation. ${ }^{79}$ This is an explicit reversal of the Lang case. At the end of this subsection is a clause stating that ". . . the term 'incidents of ownership' includes imcidents of ownership possessed by the decedent at his death as manager of the community." 80 In all community property states the husband is the manager of the community ${ }^{81}$ and this is so, in all but three states, ${ }^{82}$ even where the community property is made up of the wife's earnings. In those three states he does not have that power. What is the sigmificance of this clause? One possible view is this. When the commumity property subsection states that premiums paid with commumity property "shall. be considered to have been paid by the insured" it is stating this for the purpose of determining taxability based on premium payment under subsection (2)(A) of 811 (g) (a) and this is the most important basis for taxability but it only operates prospectively. For retroactive operation, and for prospective operation after January 10, 1941, when decedent did not pay premiums, the new amendment requires that "incidents of ownership" be held after January 10, 1941, under (2) (B) of 811 (g) (a) and $811(\mathrm{~g})(\mathrm{c}) .{ }^{83}$ The clause in the community property subsection, under this view, is to be given effect to achieve this purpose. One difficulty with this view is that the "incidents of ownership" under 2(B) are fixed by the terms of the insurance policy and local insurance law. The powers of management under commumity property law will not operate on the insurance policy unless the policy permits it. Taxability surely must

77 (1938) 304 U. S. 264.

78 De Lappe v. Commissioner (C. C.A.5th, 1940) 113 F. (2d) 48; Elizabeth C. McCoy (Cal. 1939) 39 B. T. A. 822; Estate of Shearn Moody (Tex. 1940) 42 B. T. A. 987.

$79 \S 404(a)(g)(4)$, see note 56 , supra.

80 Ibid.

81 Supra note 2.

82 Idaho, Nevada and Oklahoma. See note 25, supra.

88 See pp. 75-76, supra. 
rest under $2(\mathrm{~B})$ on the powers held by the decedent over the policy. Powers as manager of the community, standing alone, are not necessarily operative on the policy.

Another possible meaming of the clause is this. When a husband pays premiums out of community property, one-half of the money so used is owned by his wife under local law and the reference in this clause to the husband's powers of management may have been designed to bridge the gap of legal title by emphasis on the husband's economic control and thus seek to take the puncl out of any argnment of unconstitutionality. ${ }^{84}$ If this view is taken then unconstitutionality would follow where a policy is on the life of the wife and premiums are paid out of her earnings by the husband in a state where he has management of community property earned by her. In this situation the amendment treats the premiums as paid by her and the proceeds are taxable in her estate yet she had no power of management at any time. As we have seen, in three states she does have management over her earnings and in those states this difficulty is not present. This is surely an arguable point and it remains to be seen low it will be dealt with.

One further amendment makes some technical changes in section 826 (c) dealing with the liability of life insurance beneficiaries. ${ }^{85}$ One change permits the decedent to direct by his will that this liability shall not be imposed on the beneficiary. ${ }^{86}$ Another change seeks to clarify the extent of the beneficiary's liability. ${ }^{87}$

\section{POWERS OF APPOINTMENT}

A serious looplole has existed for a long time in the estate tax with respect to powers of appointment. At the outset it would be well to explain this peculiar dispositive device. The donor of the power,

84 See the discussion above, text to note 13 , supra, et seq., as to the constitutionality of the new estate tax amendment.

85 Supra note 56, \& 404(b).

${ }^{88}$ This is apparently designed to erase the effect of United States Trust Company of New York v. Sears (D. Conn. 1939) 29 Fed. Supp. 643, which had held the beneficiary hable even though the decedent had seemingly provided to the contrary in his will. See 1 PaUL, op. cit. supra note $1, \$ 13.55$.

87 Again the Sears case, supra note 86 , is the cause of the troubles under the old section. The trouble grew out of the term "net estate" used in calculating the extent of the beneficiary's hability. Under the old section the insurance beneficiary's liability was for that proportion of the total tax paid as the insurance proceeds (in excess of the old $\$ 40,000$ special insurance exemption) bore to the "net estate". The Sears case held that "net estate" referred to meant only the gross estate less deductions allowed by section 812 and did not permit the deduction of either the $\$ 100,000$ exemption for the basic tax under section 812 (a) or the $\$ 40,000$ exemption for the additional tax under section 935(c). The effect of this decision was to reduce the beneficiary's liability. The new amendment corrects this by allowing the deduction of the $\$ 40,000$ (now $\$ 60,000$ ) exemption under section 935(c). See SEN. REP. No. 1631, op. cit. supra note 12, at 236. The point is also discussed in 1 PAUL, op. cit. supra note 1, \$13.55. 
usually by will, gives to the donee (appointor) the power to appoint the person or persons who shall succeed to the transferred property upon the termination of some intermediate estate. It is typically a method of family settlement. Thus, $H$ leaves his estate to $W$ for life with a general power in her to appoint the remainder. The commonlaw view was that the property passed from donor to appointee, nothing passing from donee to appointee when the power was exercised. ${ }^{85}$ The power may be exercised either by will or by deed inter vivos. The same flexibility of disposition is possible under this device as is achieved by leaving the estate to the wife in fee. In fact, since $W$ might appoint to herself, her estate or her creditors, she may be treated as the owner in fee. ${ }^{89}$

In the Revenue Act of 1918 Congress required the inclusion in the decedent's estate of all property "passing under a general power of appointment exercised by the decedent" by will or by certain testamentary transfers inter vivos. ${ }^{90}$ This has remained substantially unchanged. ${ }^{91}$ The loopholes in this provision have been fully explored elsewhere. ${ }^{92}$ It is enough to point out that before the property was includible in the decedent's estate the power must have been a "general" as distinguished from a "special" power, ${ }^{93}$ the power must have been exercised and the property must have passed by the exercise. ${ }^{94}$ A variety of simple devices was available to avoid taxability under this provision..$^{95}$

The amendment made by the Revenue Act of $1942^{\circ 0}$ is an effec-

88 Emmons v. Shaw (1898) 171 Mass. 410, 50 N. E. 1033.

${ }^{89}$ See Thompson v. Pew (1913) 214 Mass. 520, 102 N. E. 122.

9053 STAT. (1939) 122, 26 U. S. C. (1940) $\$ 811(\mathrm{f})$.

91 The Revenue Act of 1932,47 STAT. (1932) $279, \S 803(\mathrm{~b})$, added only additional testamentary transfers inter vivos.

921 Paur, op. cit. suppra note 1, c. 9; Griswold, Powers of Appointment and the Federal Estate Tax (1939) 52 Harv. L. Rev. 929; Schuyler, Powers of Appointment and Especially Special Powers: The Estate Taxpayer's Last Stand (1939) 33 Irr. L. Rev. 771.

93 The Property Restatement (Am.L. Inst. 1940) \$320, defines general powers as those exercisable in favor of the donee (or his estate if the power is testamentary) and special powers as those not exercisable in favor of the donee or his estate and restricted to a reasonably small class. The Restatement points out that there is an area not covered by either definition. See also U.S. Treas. Reg. (1942) \$81.24.

94 Helvering v. Grinnell (1935) 294 U. S. 153.

95 These are detailed by 1 PAUL, op. cit. supra note 1, c. 9; and Griswold and Schuyler, both op. cit. supra note 92.

96 Revenue Act of 1942, § 403 (a) amending I. R. C. $\$ 811$ (f) [53 STAT. (1939) 122, 26 U.S. C. (1940) $\S 811(\mathrm{f})]$ to read as follows:

" (f) Powers of ApPoINTAEENT.-

"'(1) IN GENERAL.-To the extent of any property (A) with respect to which the decedent has at the time of his death a power of appointment, or (B) with respect to which he has at any time exercised or released a power of appointment in contemplation of death,.or (C) with respect to which he has at any time exercised or released a power of appointment by a disposition intended to 
tive treatment of this whole problem. Gone are the distinction between "general" and "special" powers, questions of "passing" and the requirement of "exercise". Gone with these points are the loopholes that had opened so wide. Instead a new scheme is set up. All property is to be included in the estate with respect to which decedent holds "a power of appointment" at his death or with respect to which he has "exercised or released" a power of appointment inter vivos by making any of the transfers treated as testamentary under the Act. The term "power of appointment" is broadly defined to include "any power to appoint exercisable by the decedent either alone or in conjunction with any person" except two sorts of powers. These are (1) a power to appoint within a specified family group from which the decedent is excluded and to charities recognized under I.R.C. sections 811 (d) and 861(a)(3); and (2) a power to appoint "within a restricted class" not exercisable for the benefit of the de-

take effect in possession or enjoyment at or after his death, or by a disposition under which he has retained for his life or for any period which does not in fact end before his death (i) the possession or enjoyment of, or the right to the income from, the property, or (ii) the right, either alone or in conjunction with any person, to designate the persons who shall possess or enjoy the property or the imcome therefrom; except in case of a bona fide sale for an adequate and full consideration in money or money's worth.

"'(2) Definition of Power of Appointment.-For the purposes of this subsection the term "power of appointment" means any power to appoint exercisable by the decedent either alone or in conjunction with any person, except

"'(A) a power to appoint within a class which does not include any others than the spouse of the decedent, spouse of the creator of the power, descendants of the decedent or his spouse, descendants (other than the decedent) of the creator of the power or his spouse, spouses of such descendants, donees described in section 812 (d), and donees described in section 861(a) (3). As used in this subparagraph, the terin "descendant" includes adopted and illegitimate descendants, and the term "spouse" includes former spouse; and

"'(B) a power to appoint within a restricted class if the decedent did not receive any beneficial interest, vested or contingent, in the property from the creator of the power or thereafter acquire any such interest, and if the power is not exercisable to any extent for the benefit of the decedent, his estate, his creditors, or the creditors of his estate.'

"If a power to appoint is exercised by creating another power to appoint, such first power shall not be considered except under subparagraph (A) or (B) from the definition of power of appointment to the extent of the value of the property subject to such second power to appoint. For the purposes of the preceding sentence the value of the property subject to such second power to appoint shall be its value unreduced by any precedent or subsequent interest not subject to such power to appoint.

"'(3) Date of ExISTEnce of Power.-For the purposes of this subsection the power of appointment shall be considered to exist on the date of the decedent's death even though the exercise of the power is subject to a precedent giving of notice or even though the exercise of the power takes effect only on the expiration of a stated period after its exercise, whether or not on or before the date of the decedent's death notice has been given or the power has been exercised." " 
cedent, his estate or creditors and if decedent holds no interest in the property.

The power of appointment is an important and flexible device for the disposition of property within a family group. ${ }^{07}$ The obvious purpose of the first exception above is to maintain the utility of powers when put to this use. The purpose of the second exception is not so plain. It is doubtless with design that the new term, "within a restricted class", is employed rather than the old "special power", but its novelty leaves it so far with only verbal content. The Report of the Senate Committee tells us that "This provision applies to a power possessed by a disinterested trustee or one occupying a similar status to appoint within a relatively small class. For example, a power to appoint within a class composed of $A$ 's children would be a power to appoint within a restricted class. On the other hand, a power to appoint to anyone except $A$ and his family would not be a power confined to a restricted class." 98 The reference to "a distinterested trustee" is strange. If the power is held in trust the property is certainly not taxable in the estate of the trustee on his death. ${ }^{90}$ The reference to "one occupying a similar status" is a little more helpful. Evidently the purpose is to except powers held by a disinterested person (one holding no interest in the property) who though not a member of the family group specified in the first exception may hold a power to appoint within such a group (here termed "a restricted class"). This would cover cases where the power is held by a close friend or relative. Under this view the "restricted class" would be one that is substantially the same as the immediate family group specified under the first exception but plaiuly it is not identical with it and how much additional leeway this second exception provides must await administrative and judicial construction.

A special paragraph deals with powers which are exercised by the creation of another power. ${ }^{100}$ The purpose of this paragraph is to prevent tax avoidance by the creation of a power of one of the excepted

97 It was not intended that the amendments should have the effect of encouraging the use of gifts of a life tenancy and remainder. The inflexihility of the latter device makes its use undesirable from a social point of view in the family settlement situation. This point is fully developed in the recent debate in the pages of the Harvard Law Review between Professors Griswold and Leach. See Leach, Powers of Appointment and the Federal Estate Tax-A Dissent (1939) 52 HARv. L. REv. 961, and Griswold, In Reply, ibid. at 967.

${ }^{88}$ SEN. REP. No. 1631, op. cit. supra note 12, at 233. H. R. No. 2333, op. cit. supra note 12 , at 161 , contains identical language.

99 Reed v. Commissioner (C. C. A. 5th, 1930) 36 F. (2d) 867; Rose v. Commissioner (C. C. A. 6th, 1933) 65 F. (2d) 616; Estate of Robert L. Holt (N. C. 1928) 14 B.T.A. 564. In making the statement in the text it is assumed, of course, that the power is not held in trust under circumstances which would call for a disregard of the trust under sections 811 (c) or (d).

${ }^{100}$ See the last paragraph of section 403 (a)(f)(2), supra note 96. 
types with authority to the donee to exercise it by creating another power of the same type. Under the common law, estates may be tied up in this manner for the period allowed by the rule against perpetuities. ${ }^{101}$ In at least one state (Delaware) ${ }^{102}$ they may be tied up indefinitely in this way. The need for a special provision to prevent serious tax avoidance in this type of situation should be apparent. The amendment deals with this by excluding from the two excepted types of powers, and thus subjecting to taxation, property covered by any power exercised by the creation of another power. ${ }^{103}$

The gift tax ${ }^{104}$ is also amended to tax "an exercise or release" of

101 Leach, Powers of Appointmient (1938) 24 A. B. A. J. 807, 809.

102 Del. Laws 1933, p. 678.

103 This will operate as follows (assume that the power is one of the types excepted):

(a) $A$ leaves property to $B$ for life with power to appoint; $B$ appoints to $C$; $C$ leaves the property to $D$ for life with power to appoint; $D$ appoints to $E$ and so on. Estate tax on the death of $A, C$ and $E$ but none on the death of $B$ or $D$.

(b) $A$ leaves property to $B$ for life with power to appoint by creation of another power; $B$ appoints to $C$ for life with power to appoint by creation of another power; $C$ appoints to $D$ in the same way; $D$ appoints to $E$ in the same way. Estate tax on the death of $A, B, C, D$ and $E$.

(c) If the rule against perpetuities is not violated the following variation is pos sible with its attendant tax saving: $A$ leaves property to $B$ for life with power to appoint; $B$ appoints to $C$ for life, remainder to $D$ for life, remainder to $E$ in fee. Estate tax on the death of $A$ and $E$ but none on the death of $B, C$ or $D$. Necessarily the utility of this will depend upon the situation in a particular family.

104 Revenue Act of 1942, \$452. "Powers of APPOINTMENT.-

"(a) GENERAL RULE. Section 1000 (relating to imposition of gift tax) is amended by inserting at the end thereof the following new subsection:

" (c) Powers of APPOINTMENT. An exercise or release of a power of appointment shall be deemed a transfer of property by the individual possessing such power. For the purposes of this subsection the term "power of appointment" means any power to appoint exercisable by an individual either alone or in conjunction with any person, except-

" '(1) a power to appoint within a class which does not mclude any others than the spouse of such individual, spouse of the creator of the power, descendants of such individual or his spouse, descendants (other than such individual) of the creator of the power or his spouse, spouses of such descendants, donees described in section 1004 (a) (2), and donees described in section 1004(b). As used in this paragraph, the term "descendant" includes adopted and illegitimate descendants, and the term "spouse" imcludes former spouse; and

"'(2) a power to appoint within a restricted class if such individual did not receive any beneficial imterest, vested or contingent, in the property from the creator of the power or thereafter acquire any such interest, and if the power is not exercisable to any extent for the benefit of such individual, his estate, his creditors, or the creditors of his estate.

"If a power to appoint is exercised by creating another power to appoint, such first power shall not be considered excepted under paragraph (1) or (2) from the definition of power of appointment to the extent of the value of the property subject to such second power to appoint. For the purposes of the preceding sentence the value of the property subject to such second power to appoint shall be its value unreduced by any precedent or subsequent imterest not subject to such power to appoimt.'

“(b) Powers Wity Respect to Which AMenduents Not Appitcable.-

"(1) The amendunents made by this section shall not apply with respect to

a power to appoint, created on or before the date of enactment of this Act, 
a power of appointment ${ }^{105}$ and the definition of a power with the two excepted types is in the same language as in the estate tax amendment. Both the estate and gift tax amendments contain very similar provisions to avoid retroactive operation in certain instances and to permit holders of powers to release them tax free if this is done before January 1, 1943..$^{106}$ Another amendment imposes estate tax liability on the recipient of property by appointment. ${ }^{107}$ This is similar

which is other than a power exercisable in favor of the donee of the power, his estate, his creditors, or the creditors of his estate, unless such power is exercised after the date of enactment of this Act.

"(2) The amendments made by this section shall not become applicable with respect to a power to appoint created on or before the date of enactment of this Act, which is exercisable in favor of the donee of the power, his estate, bis creditors, or the creditors of his estate, if at such date the donee of such power is under a legal disability to release such power, until six months after the termination of such legal disability. For the purposes of the preceding sentence, an individual in the military or naval forces of the United States shall, until the termination of the present war, be considered under a legal disability to release a power to appoint.

“(c) RELEASE ON OR BEFORE JANUARY 1, 1943'

"(1) A release of a power to appoint before January 1, 1943, shall not be deemed a transfer of property by the individual possessing such power.

"(2) This subsection shall apply to all calendar years prior to 1943."

105 For inethods of release see generally PROPERTX RESTATEMIENT (Am. L. Inst. 1940) $\$ \$$ 334-336, and also Simes, Powers in Trust and the Termination of Powers by the Donee (1927) 37 Yale L. J. 211; cf. (1940) 28 CaLIF. L. Rev. 399.

106 For the gift tax amendment see supra note 104. The estate tax amendment reads as follows:

Revenue Act of 1942, \$ 403(d). "Powers With Respect to Which Amendments Not Applicable.-

"(1) The amendments made by this section shall not apply with respect to a power to appoint, created on or before the date of the enactment of this Act, which is other than a power exercisable in favor of the decedent, his estate, his creditors, or the creditors of his estate, unless such power is exercised after the date of the enactment of this Act.

"(2) The amendments made by this section shall not become applicable with respect to a power to appoint created on or before the date of enactment of this Act, which is exercisable in favor of the decedent, his estate, his creditors, or the creditors of his estate, if at such date the donee of sucl power is under a legal disability to release such power, until six months after the termination of such legal disability. For the purpose of the preceding sentence, an individual in the military or naval forces of the United States shall, until the termination of the present war, be considered under a legal disability to release a power to appoint.

"(3) The amendments made by this section shall not apply with respect to any power to appoint created on or before the date of the enactment of this Act if it is released before January 1, 1943, or within the time limited by paragrapl (2) in cases to which such paragrapl is applicable; or if the decedent dies before January 1, 1943, or within the time limited by paragraph (2) in cases to which such paragraph is applicable, and such power is not exercised."

According to a recent ruling of Mr. Randolph Paul, General Counsel of the Treasury, dated November 6,1942, these provisions permit partial releases which cut down the power so as to bring it within one of the restricted classes of powers not subject to the tax. C. C. H. Inher. Tax Serv. (7th ed.) II 6017.

107 Revenue Act of 1942, § 403 (c), amending I. R. C. §826 [53 StAT. (1939) 127, 26 U.S. C. (1940) § 826]. 
to the liability imposed on life insurance beneficiaries. ${ }^{108}$ I.R.C. sections 812 (d) and 861 (a) (3), relating to charitable deductions, are also amended to permit the deduction of amounts going to a charity through the exercise of a power by decedent. ${ }^{109}$

\section{EXEMPTIONS AND CREDITS}

The new Act eliminates the old $\$ 40,000$ special exemption of insurance proceeds receivable by beneficiaries other than the executor $^{110}$ but at the same time increases the old $\$ 40,000$ specific exemption for the additional estate tax to $\$ 60,000 .{ }^{111}$ At the same time the cumulative exemption of $\$ 40,000$ under the gift tax is reduced to $\$ 30,000$. $^{112}$ A new specific exemption of $\$ 2000$ is allowed for the estates of nonresidents who are not citizens. ${ }^{113}$

The annual exclusion-to be distinguished from the cumulative exemption-from gifts made is reduced from $\$ 4000$ to $\$ 3000 .^{114}$ Under the Revenue Act of 1932 this annual exclusion did not extend to gifts of "future interests in property" ${ }_{115}$ The Revenue Act of 1938 added a clause so that it did not extend to "gifts in trust". This 1938 amendment was designed to deal with the problem as to how many donees there were when one trust was credited for a number of beneficiaries or a number of trusts were created for the same person as beneficiary. There had been disagreement on this point among lower courts. ${ }^{117}$ The Supreme Court recently settled the point

108 Note 56, supra.

109 Revenue Act of $1942, \S 403$ (b).

110 Revenue Act of $1942, \S \S 404(\mathrm{a})$ and $414(\mathrm{~b})$, amending I. R.C. $\$ \S 811(\mathrm{~g})$ and 826(c) [53 STAT. (1939) 122, 128, 26 U.S.C. (1940) $\$ \$ 811(\mathrm{~g}), 826(\mathrm{c})]$.

111 Revenue Act of 1942 , $\$ 414$ (a), amending I. R. C. $\$ 935$ (c) [53 Stat. (1939) 141, 26 U.S. C. (1940) §935(c)].

112 Revenue Act of 1942, $\$ 455$, amending I. R. C. $\$ 1004$ [53 STAT. (1939) 146, 26 U.S.C. (1940) $\$ 1004]$. The reduced exemption is apphed retroactively but only for the purpose of computing the tax for the calendar year 1943 and subsequent calendar years.

113 Revenue Act of 1942, \& 412, amending I. R.C. \& 861(a) [53 STAT. (1939) 129, 26 U. S. C. (1940) $\S 861(\mathrm{a})]$. This is designed to reheve the government of the cost of administration of very small estates, SEN. REP. 1631, op. cit. supra note 12, at 241.

114 Revenue Act of $1942, \$ 454$, amending I. R. C. $\$ 1003$ (b) (2) [53 STAT. (1939) 146,26 U.S.C. (1940) $\S 1003$ (b) (2) ]. The result is that the old exclusion of $\$ 5000$ applies for gifts made from June 6, 1932 (the effective date of the gift tax) to the end of 1938; the old $\$ 4000$ exclusion applies for the years 1939 through 1942 ; and the new $\$ 3000$ exclusion applies for 1943 and subsequent years.

115 Revenue Act of 1932, § 504(b), now I. R. C. \$1003(b) [53 Stat. (1939) 146, 26 U.S. C. (1940) § $1003(\mathrm{~b})]$.

116 Revenue Act of 1938, § 505, now I. R. C. § 1003 (b) (2) [53 Stat. (1939) 146, 26 U.S. C. (1940) \$ $1003(\mathrm{~b})(2)]$.

117 Welch v. Davidson (C. C. A. 1st, 1939) 102 F. (2d) 100, held that each beneficiary of a trust is the donee while Commissioner v. Krebs (C. C. A.3d, 1937) $90 \mathrm{~F}$. 2d) 880 and Commissioner v. Wells (C. C. A. 7th, 1937) 88 F. (2d) 339, held that the trustee was the donee. 
in Helvering $v$. Hutchings ${ }^{118}$ by holding that each beneficiary of a trust is the donee and is entitled to one annual exclusion. The trust is disregarded. The result was that there was no further need to discriminate against gifts in trust in order to prevent gift tax avoidance through the device of multiple trusts for the same beneficiary. ${ }^{110}$ The 1938 amendment is erased and the exclusion provision is put back to its original form. Under this only gifts of "future interests in property" are not entitled to the annual exclusion and gifts may, of course, take the form of gifts in trust. ${ }^{120}$

The provision for the $80 \%$ credit for state death taxes against the basic estate tax under I. R. C. sections 810 and 860 developed a troublesome point in that any gift tax credits were first applied against the basic estate tax to fix the amount of the federal tax against which the $80 \%$ credit for state taxes operated. ${ }^{121}$ This is now changed. The credits are reversed and hereafter the credit for state death taxes will be applied before, rather than after, the federal gift tax credits. ${ }^{122}$

\section{DEDUCTIONS}

Heretofore the deductibility of "claims against the estate" was limited by the requirement that they were "contracted bona fide and for an adequate and full consideration". ${ }^{123}$ When this language was applied literally to charitable pledges made by the decedent during his lifetime the result was the unfortunate decision in Taft $v$. Commissioner. ${ }^{124}$ Deduction was there disallowed even though the pledges were enforceable against the estate under local law. The 1942 Act changes this and relieves charitable pledges from the consideration requirement. ${ }^{125}$ Hereafter they will be treated as bequests and deductibility determined under I.R.C. section 812 (d) dealing with bequests to specified charities.

Under the old Code provision there was uncertainty about the

118 (1941) 312 U. S. 393.

110 See SEN. REP. 1631, op. cit. supra note 12, at 243.

120 On this see United States v. Pelzer (1941) 312 U. S. 399; Ryerson v. United States (1941) 312 U. S. 405.

121 I. R. C. $\$ 813$ (b) [53 STAT. (1939) 125, 26 U.S. C. (1940) § 813(b)]. The result was that if state death taxes were drawn to absorb the maximum credit under this provision, the yield of the state tax was reduced.

122 Revenue Act of $1942, \S 410$, anjending I. R. C. $\S 813(\mathrm{a})(1),(\mathrm{a})(2)(\mathrm{A})$ and 813 (b) [53 Stat. (1939) 125, 26 U.S. C. (1940) § 813]. See Sen. Rep. 1631, op. cit. supre note 12, at $240-241$.

123 I. R. C. $\$ 812$ (b) [53 STaT. (1939) 123, 26 U.S. C. (1940) §812(b)].

124 (1938) 304 U. S. 351.

125 Revenue Act of 1942, $\$ 406$, amending.I. R. C. $\$ \S 812$ (b) and 861 (a) (1), [53 STAT. (1939) 123, 129, 26 U.S.C. (1940) $\$ 8812($ b), $861($ a) (1)]. 
deductibility of certain types of bequests to charity. ${ }^{126}$ If, for example, decedent left his residuary estate to charity and a specific legatee disclaimed his legacy so that an additional amount fell into the residuary estate and so passed to the charity there was doubt as to whether this additional annount was deductible. It did not pass as a "bequest" of the decedent but rather grew out of the disclaimer by the legatee after decedent's death. The same problem exists when discretion is vested in a person to direct that property shall or shall not go to a charity and that person disclaims his power so that the property in fact goes to a charity named by decedent. A new amendment ${ }^{127}$ disregards the events after death and fastens on the important fact that the deduction should be allowed if in fact the property passes to a charity designated by decedent. This result is accomplished by declaring that deduction will be permitted if the amount that passes to charity falls into decedent's bequest as a result of an "irrevocable disclaimer" of a bequest or power. The disclaimer must be made before the date for the filing of the estate tax return. ${ }^{128}$ This amendment is made applicable to estate of decedents dying after the date of the enactment of the Internal Revenue Code on February 10, 1939. ${ }^{129}$

A techmical annendment is made to I. R. C. section 811 (d) (relating to charitable deductions) so that deduction will not be allowed in any case when any donee is engaged in carrying on propaganda or attempting to influence legislation. ${ }^{130}$

An important amendment limits all allowable deductions under I. R. C. section 812 (b) to the amount of the property in the estate that is subject to the payment of claims. ${ }^{131}$ It is apparent that when the estate tax sweeps into the gross estate items of property that have been transferred by the decedent during his lifetime the result is that

126 Note (1942) 30 CALIF. L. REv. 556.

127 Revenue Act of 1942, $\$ 408$, amending I. R. C. $\$ \S 812$ (d) and 861 (a) (3) [53 STAT. (1939) 124, 130, 26 U.S. C. (1940) $\$ \$ 812$ (d), 861(a) (3)].

128 Ibid. The estate tax return must be filed within fifteen months after the date of death, I. R. C. $\$ 821$ (b) [53 STaT. (1939) 126, 26 U. S. C. (1940) $\$ \$ 21$ (b)] ]. U. S. Treas. Reg. 105 (1942) § 81.63. The Report of the Senate Finance Committee states that while the disclaimer must be made before that date it need not be irrevocable at that time if it becomes irrevocable before the expiration of the statute of limitations for the redetermination of the estate tax. SEN. REP. 1631, op. cit. supra note 12, at 240. (This statute of limitations is normally three years after the return was filed, I. R. C. $\S 874$ (a) (b) [53 STAT. (1939) 135,26 U.S. C. (1940) $\$ 874$ (a) (b)].) The language of the amendment is far from clear on this point but perhaps the view taken by the Senate Finance Committee can be extracted from it.

129 Supra note 127.

130 Revenue Act of $1942, \S 409$, amending I. R. C. $\$ \S 812$ (d) and 861 (a) (3), see note 127, supra.

181 Revenue Act of $1942, \S 405$, amending I. R. C. $\$ 812(b)$ and (c) [53 STAT. (1939) $123,124,26$ U.S. C. (1940) \& 812 (b), (c)]. 
the property in the hands of the executor and subject to the payment of claims under local law may in fact be only a small amount. After all the "gross estate" is defined by statute and has no necessary relation to property available to pay claims. The old provision took no account of this and permitted the deduction of claims without regard to whether there was any property out of which they might be paid. The result was a boon to taxpayers. If a taxpayer's gross estate, for example, was made up entirely of life insurance proceeds and property transferred in contemplation of death there might be no property at all in the hands of the executor which would be subject to the payment of claims under local law. In such a case if the allowable claims exceeded the gross estate the transfers would be made tax free..$^{132}$ The 1942 amendment is designed to put an end to this by limiting deductibility to the amount of claims that are payable out of property in the hands of the executor. ${ }^{133}$ The same principle is applied in a complicated amendment to the section relating to deductions for property previously taxed..$^{134}$

\section{ODDS AND ENDS}

A technical amendment to I. R. C. section 827 (b), dealing with transferee liability, extends the personal liability of transferees to all persons receiving property included in the gross estate. ${ }^{135}$ Heretofore section 827 (b) limited this liability to transferees who took under some but not all of the inter vivos transfers that were treated

132 The Senate and House Committee Reports describe this situation. SEN. REP. 1631, op. cit. supra note 12 , at 236 ; H. R. REP. 2333 , op. cit. supra note 12 , at 163 ; see also 1 PAUL, op. cit. supra note $1, \$ 10.26$.

133 Section 405 (a) does this by inserting the following new sentence in I. R. C. \$ 812(b) [53 STAT. (1939) 123, 26 U.S.C. (1940) \$ 812(b)] after the old second sentence: "There shall be disallowed the amount by which the deductions specified in paragraphs (1), (2), (3), (4), and (5) exceed the value, at the time of the decedent's death, of property subject to claims. For the purposes of this section the term "property subject to claims" means property includible in the gross estate of the decedent which, or the avails of which, would, under the applicable law, bear the burden of the payment of such deductions in the final adjustment and settlement of the estate. . . ." This is an adoption of the construction given to the unamended section in U. S. Treas. Reg. 105 (1942) § 81.29. Lower court decisions had rejected this construction, however. See Hclvering v. O'Donnell (C. C.A. 2d, 1938) 94 F. (2d) 852 ; Commissioner v. Lyne (C. C. A. 1st, 1937) 90 F. (2d) 745, (1938) 51 HARv. L. Rev. 745.

134 Section 405, supra note 131. Other technical changes are made in the Code provisions dealing with deductions on account of property previously taxed, Revenuc Act of 1942, § 407, amending I. R. C. $\$ \S 812$ (c) and 861 (a) (2) [53 STAT. (1939) 124, 130, 26 U.S. C. (1940) $\$ \$ 812(\mathrm{c}), 861$ (a) (2)].

135 Revenue Act of 1942, §411, amending I. R. C. $\$ \S 827$ (b) and 900(c) [53 STAT. (1939) 128, 137, 26 U.S.C. (1940) $\$ \$ 827$ (b), 900(e) ]. Under this amendment personal liability exists, as before, only if the tax is not paid by the executor but it extends to a transferee of property included in the gross estate under section 811 (b), (c), (d), (c), (f) or (g) [53 STAT. (1939) 120, 26 U.S. C. (1940) \& $811(\mathrm{~b})-(\mathrm{g})]$. 
as testamentary under section $811 .^{136}$

The period for filing petitions with the Board of Tax Appeals is extended from ninety to one hundred and fifty days if the notice of deficiency is addressed to an executor, in the case of the estate tax, or to a donor, under the gift tax, outside the States of the Union and the District of Columbia. ${ }^{137}$ This change was prompted by the hardship the ninety-day period might work due to delays in transporting nuail during present hostilities. ${ }^{138}$

If in a deficiency proceeding properly before it the Board of Tax Appeals (now the Tax Court of the United States ${ }^{139}$ ) finds overpayment it may determine the overpayment in the same proceeding. ${ }^{140}$ The Code has always provided, however, that the Board may not direct a refund, based on a finding of overpayment, unless overpayment had occurred within three years before ". . the filing of the claim or the filing of the petition, whichever is earlier...."141 Trouble grew out of the Board rules under which petitions may be freely amended ${ }^{142}$ for it is only through a petition for redetermination of a deficiency notice that overpayment issues may be presented before the Board. The question had arisen as to whether the three-year limitation operated from the date of an original petition or a later amended petition. ${ }^{143}$ It was recently held that the Board's jurisdiction was limited to overpayment issues raised in a petition filed within the three-year period and that issues raised in a later amendment were not timely and could not be considered. ${ }^{141}$ The 1942 Act resolves this trouble by striking out the words "the filing of the petition" and inserting in their place the words "the mailing of the notice of deficiency". ${ }^{145}$ This is an important procedural change and will insure an earlier formulation of issues and produce greater conformity between refund proceedings brought in court and those

-138 The old provision covered only transfers taxable under section 811 (c) and insurance proceeds passing under a contract executed by a decedent in favor of a specific beneficiary, see I. R.C. $\S 827$ (b) [53 STAT. (1939) 128, 26 U.S.C. (1940) §827(b)] before this amendment.

137 Revenue Act of 1942, § 413, amending I. R. C. $\$ 871$ (a) (1)-estate tax [53 STAT. (1939) 132, 26 U.S.C. (1940) §871(a)(1)]; Revenue Act of 1942, § 456, amending I. R. C. $\$ 1012$ (a) (1)—gift tax [53 StaT. (1939) 149, 26 U.S. C. (1940) § 1012 (a) (1)]. 138 See SEN. REP. 1631, op. cit. supra note 12, at 242, 244.

139 Revenue Act of $1942, \S 504$.

140 I. R. C. $\$ 912$ [53 STAT. (1939) 139, 26 U.S. C. (1940) § 912].

141 Ibid.

142 Rules of Practice Before the United States Board of Tax Appeass (17th ed. 1942) Rule 17.

143 See the excellent discussion in Note (1941) 50 YaIE L. J. 720.

144 Commissioner v. Dallas' Estate (C. C.A. 2d, 1940) 110 F. (2d) 743.

145 Revenue Act of $1942, \S 415$, amending I. R. C. $\$ 912$-estate tax [53 STAT. (1939) 139, 26 U.S. C. (1940) § 912] ; Revenue Act of 1942, § 457, amending I.R.C. $\S 1027$ (d)-gift tax [53 STAT. (1939) 157,26 U.S. C. (1940) § 1027(d)]. 